\title{
Dilemma and Countermeasures of Human Resource Management Teachers' Professional Development under Frame of Belief
}

\author{
Zou Huoying 1, a \\ ${ }^{1}$ Guangzhou Huali Science and Technology Vocational College, Guangzhou, China \\ ${ }^{a}$ E-mail: huoyingzou@163.com
}

Keywords: belief structure; human resources management specialty; teacher career development.

\begin{abstract}
Belief is the internal determinant that people believe in the correctness of a certain understanding and consciously evaluate and regulate their own behavior. There are some difficulties in the professional development of human resources management teachers, such as the lack of innovation drive and the limited professional support. The difficulties and countermeasures of the professional development of human resources management teachers under the belief system is analyzed. Teachers' beliefs have great significance to education and teaching and the growth of individual teachers. Only teachers with firm educational beliefs can stimulate their enthusiasm for their cause and stimulate their creativity in their work. Under the guidance of belief, it is feasible to guide teachers' professional development and internalize teachers' professional ethics. Under the framework of belief, it is necessary to internalize the professional support of human resources management teachers as teachers' lofty professional ethics, bring up human resources management teachers' noble personality, constantly update their teaching ideas, insist on carrying out quality education and innovation education, and improve students' ideological and cultural quality in teaching practice imperceptibly.
\end{abstract}

\section{Introduction}

As a new favorite of management discipline, human resource management has attracted more and more attention. Human resource management has been paid more and more attention to, and has entered the stage of strategic management. The human resource management of our country has gone through a process from personnel management to strategic management. In this process, the human resource manager has also completed the role transformation from senior clerk to strategic partner of enterprise ${ }^{[1]}$. With the aggravation of enterprise competition, the future unpredictability is strengthened, and the competition for talents among enterprises is becoming more and more intense. Talent competition becomes the core of enterprise competition. As the most active and core resources in enterprises, people are paid more and more attention. Who has mastered the talent, who has mastered the core competitiveness of human resources, who has mastered the magic weapon of 
winning the competition. This brings more challenges to our human resource manager, how to treat human resource strategically, how to manage it strategically, how to make human resource strategy and enterprise strategy better match the overall strategy of enterprise. Human resources should be considered by human resource managers. The teacher of human resource management is the important guide of human resource management. In recent years, more and more human resources teachers pay attention to their career planning and development, and their planning and development also affect the future of schools, teachers and students ${ }^{[2]}$. Driven by belief ideals, this paper studies the plight and countermeasures of teachers' professional development in human resources management, and probes into the teachers' professional characteristics under the framework of teachers' ideals and beliefs, which mainly include the pursuit of sublimity in the realm and the nature of the value orientation. There are five aspects: happiness in work attitude, renewal in professional knowledge and creativity in practice. On the basis of belief structure, we should promote teachers' professional respect, establish a reasonable path of teachers' career development and promotion ladder, bring up human resources management teachers' noble personality, and constantly renew their teaching ideas, the teacher training system is fully improved.

\section{Career development dilemma of teachers in human resource management}

After 28 years of development, human resource management has been widely recognized by the society. The concept of enterprise has changed from the initial personnel management to the present human resource management. As of June 2014, there were 390 human resources management colleges and universities in China. By 2008, 22,955 college graduates had been sent to the society, and the enrollment scale had risen from 2,112 in 1999 to 30,850 in 2008. There is a general lack of self-management of professional career in the planning of professional career of human resources management teachers in colleges and universities, which is mainly reflected in the following aspects $^{[3]}$.

\subsection{Not take the initiative to analyze the occupational environment}

Influenced by the traditional concept of career development, the society generally believes that college teachers are relatively stable jobs. Therefore, college teachers are also affected by this concept, lacking the awareness and ability of personal career development planning and design. On the one hand, they cannot objectively examine themselves, which is mainly subject to self-awareness and organizational evaluation of their clients ${ }^{[4]}$. On the other hand, although some teachers have personal career planning, they are mostly formed by external pressure, mostly passive and mere formality. On the one hand, teachers' autonomy and self-consciousness in personal career planning are not high; on the other hand, teachers' career planning is not high enough. The general professional environment of college teachers refers to the nature of the profession, the current situation and the development trend of the profession faced by teachers of all majors, and the special environment refers to the human resource management. Professional teachers' specific work content, job requirements, development prospects, job matching, such as human resources management professional comprehensive, practical.

\subsection{Lack of clear career positioning}

The specialty of human resource management is comprehensive and practical, so it is very suitable for vocational education, which meets the requirements of comprehensive reform in the field of national education, and is conducive to the adjustment of employment structure. Therefore, in this special professional environment, the urgent task of human resources management teachers 
is not to go from theory to theory, only to adhere to the academic "pyramid", but to vigorously cultivate their own comprehensive knowledge depth and the ability to use knowledge. Go to the enterprise to see their needs, research must be closely linked to the real situation of the enterprise ${ }^{[5]}$.

\subsection{Lack of opportunity sensitivity}

The habit of professional development formed for a long time makes college teachers lack due sensitivity to the environment which can affect their own professional development. In the process of their own professional development, college teachers can neither accurately and timely grasp the information and development opportunities provided by the organization, nor can they effectively use the favorable conditions and rich resources of the school to develop and improve themselves ${ }^{[6]}$. Only in accordance with the organization of the promotion path to complete their own career development. Finally, it makes it difficult to exert the superiority of university teachers, and the development of university teachers is homogenized. On the one hand, teachers do not know themselves well enough to grasp all kinds of training opportunities provided by schools, on the other hand, they fail to link training with salary and promotion opportunities.

\section{Framework of teachers' belief system in Human Resources Management}

The professional characteristics of teachers advocated by teacher education culture have become a profound cultural soil and an important driving force to cultivate a large number of future excellent teachers ${ }^{[7]}$. The rise of teacher belief study is influenced by constructivism theory. Teachers' belief in human resources management means that teachers in the field of human resources management are convinced of classroom teaching, language, learners, content, teachers' self or teacher's role in the teaching field. In the teaching process of human resource management, teachers' belief in human resource management will have a great impact on their teaching behavior. Teacher belief is of great importance to education and teaching and the growth of individual teachers.

First, teacher belief is a powerful internal driving force for teachers' self-growth and perfection. Once the teacher's belief is formed, it will become the great spiritual force that dominates the teacher's behavior, which determines the direction and firmness of the teacher's undertaking of education. Moreover, only teachers with strong educational beliefs can stimulate their enthusiasm and creativity in their work ${ }^{[8]}$. At the same time, teachers' belief is a necessary condition for teachers' professional ethics to internalize and form noble personality. Teachers' beliefs are associated with teachers' positive emotions, and teachers' emotions are internalized into teachers' noble professional ethics under the drive of their beliefs, thus creating teachers' noble personality. Teacher belief is also a firm force of supervision and evaluation in teacher education behavior. It always reminds teachers of their teaching behavior, and puts forward feedback information in time, affirms or criticizes teachers' behavior, causes teachers' emotional experience of satisfaction or self-reproach, and further deepens and strengthens teachers' educational beliefs.

Second, educational beliefs deeply influence and determine the classroom teaching of teachers. Through the teacher's teaching design, the teaching organization implements to the classroom teaching, the teacher-student relations and the school work aspect. Because belief can connect cognition with action through the action of emotion and will. Therefore, what kind of educational belief the teacher possesses will determine the way and attitude he takes towards education and teaching and students. For example, if a teacher firmly believes that any student is a potential individual, then he will not ignore the backward students in the class, but will take positive and effective ways to make every student progress ${ }^{[9]}$.

Thirdly, teachers' educational belief is a potential educational power, which has a subtle 
influence on students' attitude and behavior. Teachers' beliefs may or may be implicit in teachers. However, no matter what form of expression, it reflects the teacher's potential outlook on students and education. In daily work, teachers' educational beliefs will be consciously reflected in teachers' behaviors, thus having a positive impact on students' attitudes and behaviors. At the same time, teachers' educational beliefs are of great significance to the formation and development of students' beliefs.

\section{Countermeasures for professional development of teachers majoring in Human Resources Management}

Teachers' beliefs are of great significance to education and teaching and the growth of individual teachers. Only teachers with firm educational beliefs can stimulate their enthusiasm for their cause and stimulate their creativity in their work. Under the guidance of belief, we should guide teachers' professional development and internalize teachers' professional ethics.

\subsection{Strengthen the education of ideals and beliefs, and improve the working mechanism conducive to the professional development of human resources management teachers}

Taking the Party building as the leading factor and guiding teachers' ethics and style under the guidance of faith, this paper lays a solid ideological foundation for the professional development of young teachers. Colleges and universities should give full play to the bridging role of grass-roots party organizations, educate young teachers on the basic theory of Marxism and the Party's basic knowledge, and intensify the efforts to recruit party members among young teachers. Strengthen the cohesion and influence of the Party organization in the group of young teachers. In accordance with the requirements of the socialist core value system, teachers' moral education should be regarded as an important topic for young teachers' further training, and the minds of young teachers should be armed with advanced theories and correct concepts. Make them realize their responsibility and mission, grasp the basic ethical standards and codes of conduct they must abide by. We should regard the construction of teachers' ethics as the important foundation of the style of study and the construction of teaching style, meticulously design all kinds of thematic educational activities, expand the carrier and form, and attract young teachers to participate extensively ${ }^{[10]}$.

\subsection{Sticking to People-oriented and helping young teachers to plan their career}

Colleges and universities should combine the overall construction of teachers with the individual growth and development of teachers. According to the characteristics and practice of human resources management teachers engaged in discipline, specialty and individual, they should design a personalized career development plan. Teachers should make their own research field and direction more clear, and better realize their personal development. It is necessary to carry out a series of activities for teachers' induction education in an all-round way, implement the "1 $+1+1$ help" between excellent teachers and young teachers, and provide training and guidance to teachers in teaching, learning, values, ideology, political theory, school history, and so on. Improve their ability and accomplishment to carry out their duties. It is necessary to vigorously support young teachers in carrying out scientific research, teaching and research activities, subsidizing high-quality teaching materials, publishing academic research results, carrying out in-depth social practice activities for teachers majoring in human resources management, and producing labor through job-related exchanges. Investigation and study, investigation and visit, etc., constantly expand the space and channels for teachers to enrich their experience and realize their career. It is necessary to comprehensively promote the reform of the management system in schools, pay attention to 
protecting the enthusiasm and initiative of young teachers in the work of job title evaluation, promotion, and evaluation, so as to provide young teachers with outstanding academic level and outstanding achievements in teaching and scientific research. To offer an opportunity for an exceptional promotion.

\subsection{Keep pace with the times and learn constantly}

The time passed quickly, the knowledge was renewed faster, the information age came, the rapid development of the network economy, people's channels of receiving information became diversified, and some traditional teaching ideas and teaching methods could not hold their ground. Teachers majoring in human resources management should closely follow the pace of the times, learn to use advanced teaching methods, and understand various new teaching tools commonly used. At the same time, because of the complexity of the content of information received by students, this requires that teachers teach people to fish and teach students how to solve different problems. As the saying goes: to give students a glass of water, teachers must have a bucket of water. Therefore, if teachers want to teach students well, they must have more knowledge than students, so we teachers should keep pace with the times, keep learning and absorb new knowledge, be the guide for students to learn, if we are eliminated by the times, He loses his ability to guard his position.

\section{Conclusions}

It is necessary to further establish and perfect the professional planning mechanism in which the main party and government leaders in schools themselves take charge of the work and the functional departments of the party and government assume their respective responsibilities. On the basis of the regular investigation of teachers' ideological status, the teachers' career planning and construction under the belief structure should establish a sensitive and effective job control mechanism with clear responsibilities and clear standards. Fair and reasonable evaluation method and reward and punishment mechanism, promote the construction of human resources management teachers. Under the framework of belief, we internalize the professional support of human resources management teachers as teachers' lofty professional ethics, bring up human resources management teachers' noble personality, and constantly update their teaching ideas. Insist on quality education and innovation education, strengthen the education of ideals and beliefs, provide a more comfortable space and stage for young teachers to display their talents.

\section{References}

[1] ZHAO Qingqing, HUANG Tianmin. Multi-objective decision making based on entropy weighted-Vague sets. Journal of Computer Applications, 2018, 38(5): 1250-1253.

[2] LI Ani, ZHANG Xiao, ZHANG Boyang, et al. Research on performance evaluation method of public cloud storage system. Journal of Computer Applications, 2017, 37(5): 1229-1235.

[3] XUE D, WU L F, LI H B, et al. TraDR:a destination prediction method based on trajectory decomposition and reconstruction in geo-social networks[J]. Computer Science, 2016, 43(3):93-98.

[4] GUO Huaping, ZHOU Jun, WU Chang'an, FAN Ming. k-nearest neighbor classification method for class-imbalanced problem[J]. Journal of Computer Applications, 2018, 38(4): 955-959.

[5] LU C, SHENG W, HAN Y, et al. Phase-only pattern synthesis based on gradient-descent optimization[J]. Journal of Systems Engineering and Electronics, 2016, 27(2):297-307.

[6] Zhang Yuzhen. Research on English learning strategies under the multimedia network environment [J]. Chinese Language Journal (foreign language education and teaching), 2014, 09:92-93,95.

[7] Liu Qizhi, Gan Guosheng. Strategies for College English Vocabulary Learning in Multimedia and Network environments[J]. Modern Educational Technology, 2009(02): 71-73.

[8] Feng Lixin. A study on the effectiveness of College English Autonomous Learning Strategies in Network Multimedia Environment[J]. Modern educational technology, 2013, 01: 59-63. 
[9] Feng Lixin. A study on the effectiveness of College English Autonomous Learning Strategies in Network Multimedia Environment[J]. Modern educational technology, 2013, 01: 59-63.

[10]Chen Bingbing. MOOCS Curriculum Model: contribution and Dilemma [J]. Foreign language Audio-Visual Teaching, 2014(3): 39-40. 